\title{
Combined effects of excess boron and salinity on root histology of Zea mays L. amylacea from the Lluta Valley (Arica, Chile)
}

\author{
Efectos combinados de exceso de boro y salinidad sobre la histología de la raíz \\ de Zea mays L. amylacea del Valle de Lluta (Arica, Chile)
}

\author{
Elizabeth Bastías ${ }^{1 *}$, María B. González-Moro², Carmen González-Murua
}

\begin{abstract}
Cell structure and alterations in tissue organization were analyzed for roots of Zea mays L. amylacea as a consequence of high salinity and boron (B) levels. Saline treatment concentrations were $100 \mathrm{mM} \mathrm{NaCl}$ (Low salinity, L) and $430 \mathrm{mM} \mathrm{NaCl}$ (High salinity, H). An excess of B was supplied as boric acid to obtain $20(334 \mu \mathrm{M})$ and $40(668 \mu \mathrm{M}) \mathrm{mg} \mathrm{B} \mathrm{kg}^{-1}$ in the nutrient solution for 20 days. Our results complement other studies on the amylacea ecotype and confirm the high degree of tolerance to salinity and excess B shown by this variety. The application of B under no salt and low salinity conditions did not result in structure changes in root cortex cells nor the vascular cylinder. Under high salinity conditions amylacea root cells showed slight alterations, such as an increase in the number of rows of cells. These high salinity conditions did not result in thickness of the stele.

Key words: Amylacea, boron, histological, root, salinity.
\end{abstract}

\section{RESUMEN}

La estructura celular y las alteraciones en la organización del tejido de raíz se analizaron en Zea mays $L$. amylacea como consecuencia de altos niveles de boro (B) y de salinidad. Concentraciones de los tratamientos de salinidad fueron $100 \mathrm{mM}$ $\mathrm{NaCl}$ (baja salinidad, L) y $430 \mathrm{mM} \mathrm{NaCl}$ (alta salinidad, $\mathrm{H}$ ). El exceso de B se suministró como ácido bórico para obtener 20

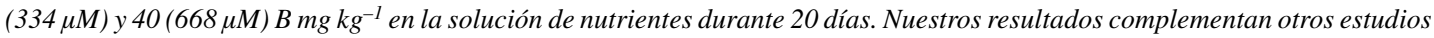
sobre el ecotipo amylacea y confirman el alto grado de tolerancia a la salinidad y el exceso de B mostrada por esta variedad. La aplicación de B bajo condiciones sin sal y baja salinidad no dio lugar a cambios en la estructura de las células de la corteza de la raíz ni el cilindro vascular. Bajo condiciones de alta salinidad células de la raíz amylacea mostraron alteraciones leves, como un aumento en el número de filas de células. Estas condiciones de alta salinidad no resultaron en el espesor de la estela.

Palabras clave: Amylacea, boro, histología, raíz, salinidad.

\section{Introduction}

Root systems are particularly affected by unfavorable conditions because they are in direct contact with the soil environment. Studies root system response of maize to salinity has focused on physiological aspects, but few studies have dealt with the effects of salinity on anatomical and histological characteristics as in the present study.

According to FAO (2008), more than $6 \%$ of world land is affected by salinity, covering about 4 Mha. Salinity is rapidly increasing on a global scale and currently affects more than $10 \%$ of arable land, which results in a decline of greater than $50 \%$ in the average yield of major crops. A decline of up to $50-70 \%$ in major crop productivity has been attributed to abiotic stress on several occasions (Mittler 2006). The primary effects of salt stress are caused by the presence of ions in the rhizosphere, limiting the extraction of water and nutrients by roots, and therefore reducing plant growth. Secondary effects are caused by ionic imbalance, which causes alterations in the structure and function of plant cells (Hernández \& Almanza 2002; Iqbal et al.

1 Departamento de Producción Agrícola, Centro de Agricultura y Biodiversidad del Desierto (CAyBIDE), Facultad de Ciencias Agronómicas, Universidad de Tarapacá. Casilla 6-D, Arica, Chile.

2 Departamento de Biología Vegetal y Ecología, Facultad de Ciencia y Tecnología, Universidad del País Vasco/Euskal Herriko Univertsitatea. Apdo. 644, E-48080 Bilbao, Vizcaya, Spain.

* Corresponding author: ebastias@uta.cl

Fecha de Recepción: 9 Septiembre, 2014.

Fecha de Aceptación: 9 Marzo, 2015. 
2014). These structural changes occur at several levels of organization; root-specific processes are of particular importance. The anatomical-morphological changes at the whole plant level allow plants to counteract the effects of salts, mainly in maintaining the efficiency of water use (Shannon at al. 1994, Hale \& Orcutt 1987). The homeostasis system is altered during the stress period when roots are forced to adopt several structural and functional modifications such as alterations of metabolism, membrane characteristics, cell wall hardening and reduction of root length (Atkinson \& Urwin 2012). Greater inhibition of root growth rather than aerial growth due to salinity increases the root/shoot ratio. Most physiological and morphological studies on the effects of salinity have been conducted mainly in the aerial part of the plant. However, the root is the organ directly exposed to saline soil, and the stress effects are shown in a stronger manner (Hajibagheri et al. 1987). The tolerance of the plant crucially depends on root tolerance to salt stress (Jeschke \& Wolf 1988). Many root studies related to anatomical changes induced by salt stress are based on research by Strogonov et al. (1964), who found no difference in the diameter of roots after 4 weeks of growth under saline conditions. Nevertheless, Neuman (1995) found an increased root diameter under saline conditions, suggesting that the reduction in cell size and increase in root diameter are adaptive advantages that enhance the survival rate of plants in saline and dry soils. Other studies (Kalaji \& Pietkiewicz 1993; Shanon et al. 1994) have shown that salt stress increases suberization and thickening of the endodermis in the root, also resulting in an increase of root diameter and vascular cylinder. Changes have been also associated with an extensive root development of tyloses, with early formation of Casparian strip and processes that allow its lignification (Flowers $\mathrm{et} \mathrm{al}$. 1986). It has been demonstrated in numerous species that salinity reduces the size of the cortical root cells. In sorghum mesocotyl narrowing is produced in a structure which could act as an ion reservoir (Wahida et al. 1998). Furthermore, in the transition zone of the hypocotyl and the root base of cotton plants, salinity exodermis formation is induced by the Caspari strip (Reinhardt \& Rost 1995). All these structures are essential to protect the root from water loss and/or from the release of solutes due to osmotic adjustment. Salinity also stimulates the development of secondary tissue lignification and increases the number of water-storing cells in the epidermis and in the cortical layer of the hypocotyl (Valenti et al. 1992). A recent study of maize seedlings grown under $100 \mathrm{mM} \mathrm{NaCl}$ conditions showed a reduction in the number of cell rows in the root cortex, a delay in the formation of the central stellar cylinder, slow division of meristematic cells, and consequently smaller elongation zone than in control plants (Belyavskaya et al. 2004). Other studies have shown that in varieties sensitive to salinity, cell damage in the root cortex is due to root cell collapse (Hakim et al. 2014). Given the importance of B as an essential element for larger plants, its deficiency and toxicity are a worldwide problem in food production because of reduced crop quality and yields, especially in arid areas (Nable et al. 1997). Salinity conditions are aggravated by the presence of B in soils and water in arid and semiarid environments. This is the case in the Lluta valley of northern Chile, where elevated levels of B in soils and irrigation water limit local agricultural production to a few landrace crops of this region, which has an annual precipitation less than $1 \mathrm{~mm}$ (Bastías et al. 2004b).

Zea mays L. amylacea is a sweet maize variety well adapted to the agro-ecological characteristics of the Lluta Valley. Physiological tolerance mechanisms to high levels of $\mathrm{NaCl}$ and $\mathrm{B}$ in amylacea maize have been studied previously with respect to salt accumulation capacity, photosynthetic assimilation and water relations in tissues (Bastías et al., 2004b), as well as root hydraulic conductance (Lo), abundance of aquaporins and ATPase activity (Bastías et al. 2004a, Martínez-Ballesta et al. 2008). Studies are very few concerning anatomical or morphological changes that verify salt and/or boron tolerance in ecotypes which are agronomically-interesting. Currently only two studies at the leaf level have been published (Bastias et al. 2013a, Bastias et al. 2013b). The present study gives findings at the root level, and aimed to determine differences in histological and anatomical changes produced as a result of excess B and salinity in the roots of Zea mays $\mathrm{L}$ amylacea.

\section{Materials and Methods}

\section{Growth conditions and experimental design}

Maize germplasm native to Northern Chile, Zea mays amylacea ("lluteño" local variety), was 
germinated in a mixture of perlite and vermiculite $(1: 1 ; \mathrm{v} / \mathrm{v})$. Seedlings were grown in plastic pots (2 L) with four plants per pot, and irrigated every two or three days to maintain soil water at field capacity with Hoagland solution containing $20 \mathrm{mM}$ $\mathrm{NO}_{3}$-N/L (González-Moro et al. 1997) adjusted to $\mathrm{pH}$ 5.5. Placement of maize pots was done randomly in a greenhouse with average day/night temperature of $25 / 18{ }^{\circ} \mathrm{C}$ and relative humidity of $60 / 70 \%$. Light intensity was set at $350 \mathrm{mmol}$ $\mathrm{m}^{-2} \mathrm{~s}^{-1}$ and supplemented with warm-white lamps (Philips SON-T AGRO 400, Belgium), providing a $14 \mathrm{~h}$-photoperiod. Nutrient solutions were prepared using deionized water. $\mathrm{pH}$, osmotic potential and conductivity were monitored weekly. During the first ten days after germination, plants were irrigated with the basic nutrient solution to maintain nonsaline growing conditions. Subsequently, when plants showed the third leaf fully expanded, they were exposed to an excess of boron and salt for 20 days. The basic nutrient solution without addition of salt (NaCl-0) or boron (B-0) was used as the control solution. This basic nutrient solution was supplemented in a factorial design with $100 \mathrm{mM}$ $\mathrm{NaCl}$ (Low salinity, L) or $430 \mathrm{mM} \mathrm{NaCl}$ (High salinity, $\mathrm{H})$, and with an excess of B supplied as boric acid to obtain $20(334 \mu \mathrm{M})$ and $40(668 \mu \mathrm{M})$ $\mathrm{mg} \mathrm{B} \mathrm{kg}{ }^{-1}$ in the nutrient solution. Harvesting of fresh plant material was done between 10:00 and 11:00 A.M.

\section{Preparation of tissue for histological studies}

Small sections were cut from roots $(4-5 \mathrm{~mm})$ of ecotype amylacea and fixed in FAA (formaldehyde 5\%: glacial acetic acid 5\%: ethanol 90\%) for 4-5 days at room temperature to favor the penetration of the fixative. Subsequently, 5 washes were carried out at intervals of $20 \mathrm{~min}$ with buffer $(100 \mathrm{mM})$ at $\mathrm{pH} 7.2$ phosphate. Then, two washes were done with distilled water for $1 \mathrm{~h}$ to remove the formaldehyde completely. Next, samples were dehydrated in an increasing series of ethanol: $70 \%, 80 \%, 90 \%$ and $100 \%$, leaving the sample overnight in methyl benzoate. For paraffin embedding the samples were first suspended in benzene and then embedded in paraffin for $4 \mathrm{~h}$. Semi-thin sections $(7-10 \mathrm{~mm}$ thick) of root were cut transversely with a rotary microtome (Leitz 1512) and then subjected to a hydration process (dewaxing) in a decreasing alcohol series: xylene (10 min), ethanol 100\% (10 min),
$96 \%$ ethanol ( $2 \mathrm{~min})$ and $70 \%$ ethanol (2 $\mathrm{min})$. Finally, samples were stained with safranin and again subjected to a dehydration process (series of ethanol and xylol). Sections were observed with a photomicroscope (Olympus BX 51) connected to a camera (Photometric Cool Snap RS) and digitized with Cool Snap (Roper Scientific, Inc.) software version 1.2. The photographs were taken in three or more random fields in different sections in order to obtain representative photographs.

\section{Results}

Plant tolerance to salinity largely depends on the salinity tolerance of the roots (Hajibagheri et al. 1987). The internal structure of the root is relatively simple compared to the stem and leaf, mainly because of the absence of nodes and internodes. Thus the arrangement of the tissue shows few differences in different levels of the root. Three tissue systems in the root of the amylacea ecotype can be easily distinguished in a cross section of the root tissue of plants after 20 days of development: epidermis, stele (vascular cylinder) and vascular tissues. The epidermis (epidermal tissue system), cortex (basal tissue system) and vascular tissue can be clearly distinguished from each other in both control and treated plants with different levels of salinity in the absence or presence of B (Figures 1, 2, 3, 4 and 5). In maize, vascular cylinder size in the stele is very noticeable in proportion to the cortex. In our ecotype, vascular tissue corresponds to approximately $50 \%$ of all tissues in the control sample and in the different treatments with excess $\mathrm{B}$ and salinity (Figures 1a, 2a, 3a, 4a and 5a).

Root epidermis is formed by parenchymal cells (Figures 1b, 2b, 3a, 4a and 5a) whose function is related to the absorption of water, ions and small molecules. Cortical cells are arranged in a variable number of rows $(10,14)$ during the entire lifecycle of monocotyledonous plants, while dicotyledonous plants lose cortex in the early stages of growth. The cells are large and compact with thinner walls (Figure 1e) due to the presence of plasmodesmata, which allow movement of substances between cells through the cortex. These cells are separated by small intercellular spaces. Immediately following the inward cortex is the cell layer is located called endodermis (ED), as seen in the Figures corresponding to the control plants (Figures 1c and 1e). This cell 

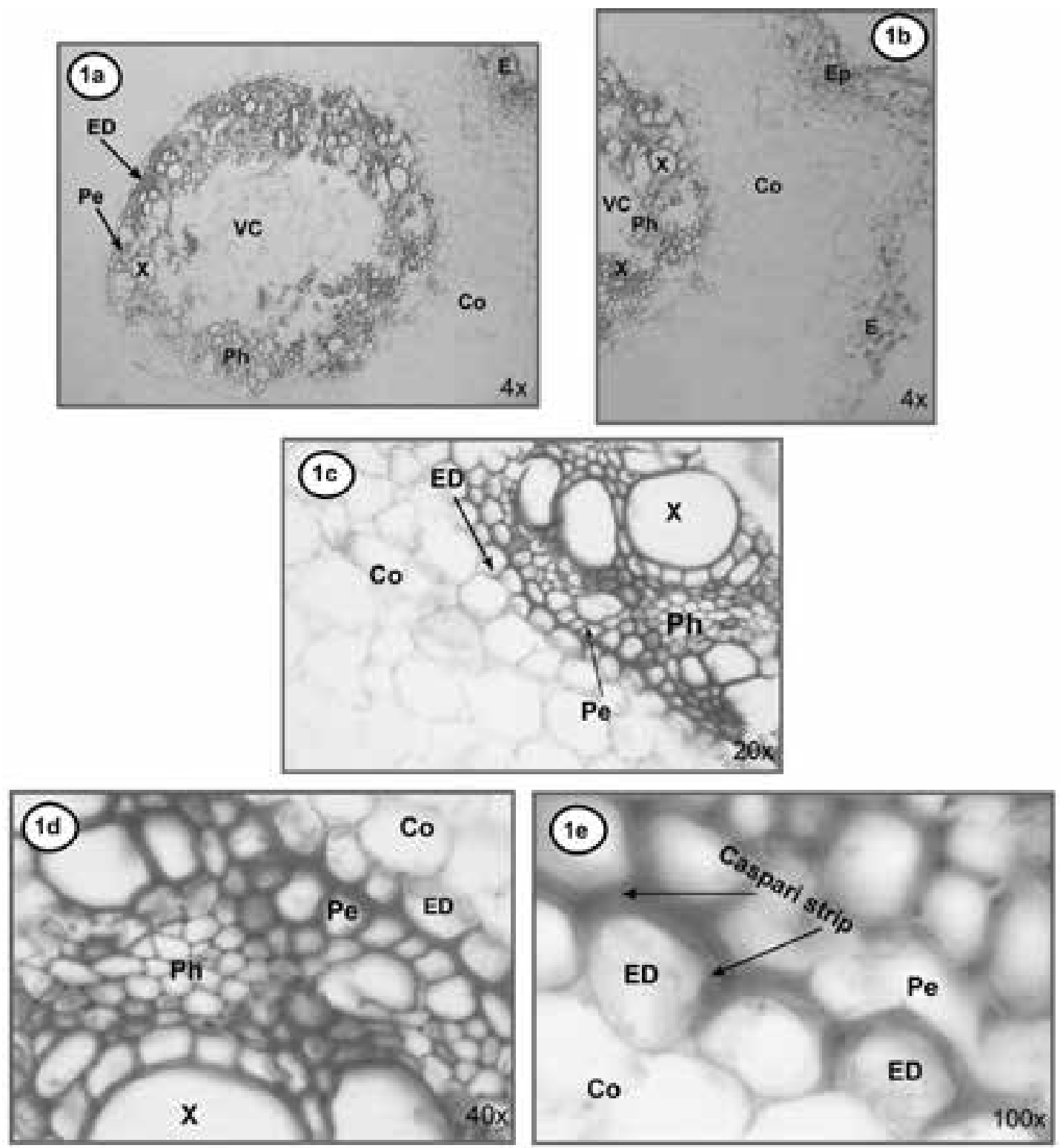

Figure 1. Light micrographs of cross sections of root in control plants of Zea mays L. amylacea. Showing the organization of the root tissue in control plants at different magnification. Samples stained with Safranin 50\%. Labels: E, epidermis, X, xylem; Pe, pericicle, ED, endodermis; Co, cortex cells; Ph, Phloem; VC, vascular cylinder.

monolayer is compact and lacks intercellular spaces. The endoderm cells are of particular interest and importance from the point of view of the movement of water and ions in the plant, as their transverse and radial cell walls include a thickening called the Casparian strip (Figure 1e). The Casparian strip is a portion of the primary wall in strip form that is infused with a lipid substance called suberin, which is highly hydrophobic and may present some lignification. The Casparian strip cell endodermis is an impenetrable barrier to the apoplastic pathway, which must necessarily cross the plasmalemma of endodermal cells. Permeability, selectivity and affinity of the channels and transporters localized in the plasmalemma of the endodermal cells ultimately determine how fast solutes are incorporated or released into the xylem (Figures 1d and 1e). 

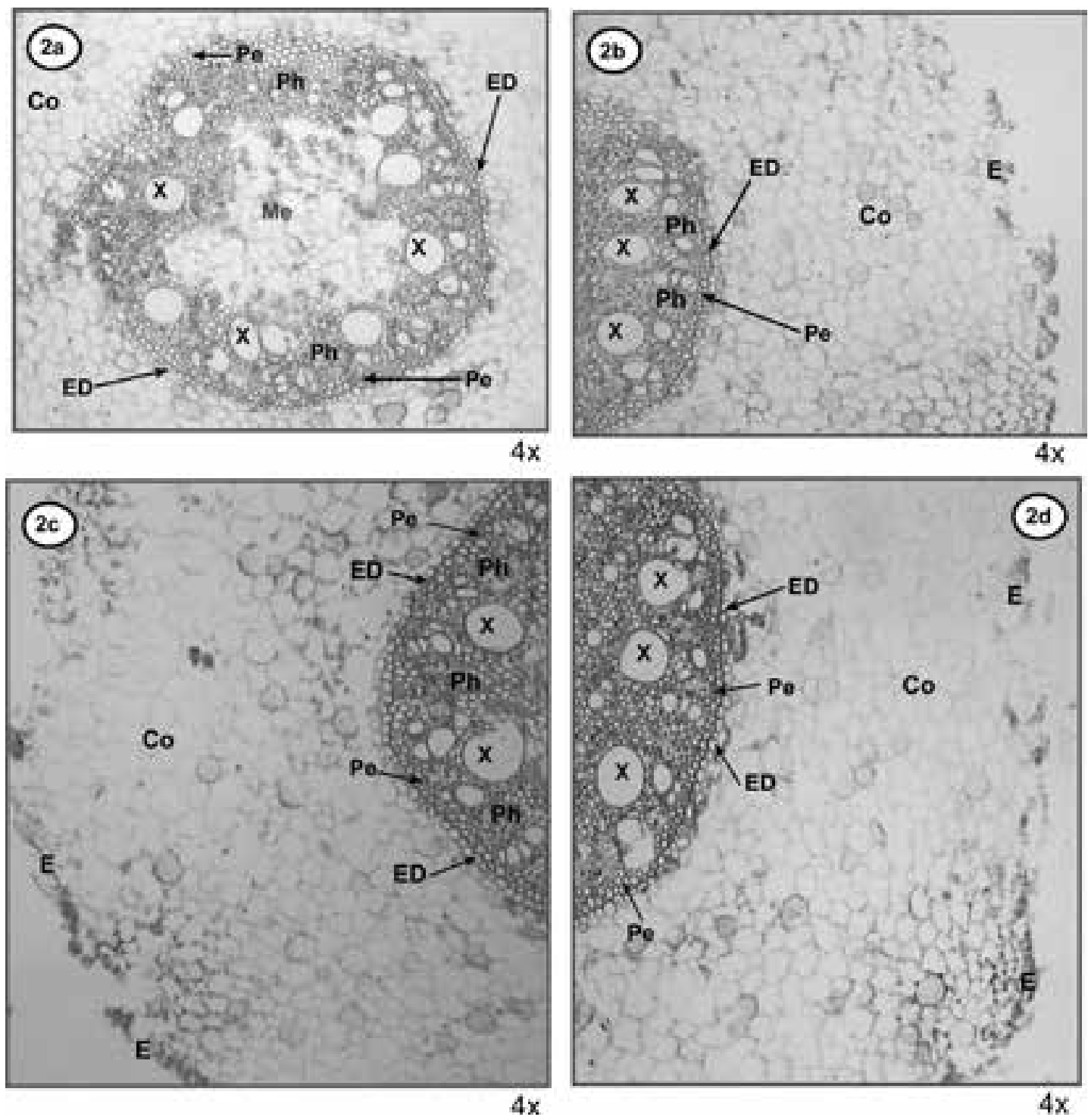

Figure 2. Light micrographs of cross sections of root in plants of Zea mays L. amylacea. Showing the organization of the root tissue in $\mathbf{B 2 0}$ (20 $\mathbf{~ m g ~ k g}^{-1}$ of B) at different magnification. Samples stained with Safranin 50\%. Labels: E, epidermis, X, xylem; $\mathrm{Pe}$, pericicle, ED, endodermis; Co, cortex cells; $\mathrm{Ph}$, Phloem; VC, vascular cylinder.

Xylem $(\mathrm{X})$ and phloem $(\mathrm{Ph})$ elements in the amylacea ecotype under control conditions are surrounded by a layer of living cells, composed of one or three rows of cells, known as the pericycle (Pe) (Figures 1c, 1d and 1e). The pericycle plays various important roles at the time of lateral root formation and development of the vascular cambium. The vascular cambium is a meristematic region which is towards the inside of the xylem and phloem (to the outside in the case of the dicots), but in the case of monocotyledonous plants such as maize, conducting vessels are arranged alternately in the vascular cylinder (Figure 1c). Salinity treatments in the presence or absence of B did not cause major changes in the ecotype amylacea regarding the organization of root tissue after 20 days under stress. As may be seen in the cross sections of the roots from plants treated with $\mathrm{B}\left(20\right.$ and $\left.40 \mathrm{mg} \mathrm{kg}^{-1}\right)$ and $\mathrm{NaCl}$ (100 mM and $430 \mathrm{mM}$ ) (Figures 3, 4 and 5), there were significant changes in the root structure.

No increase in the number of cell layers was observed in the area of the cortex and stele, nor 

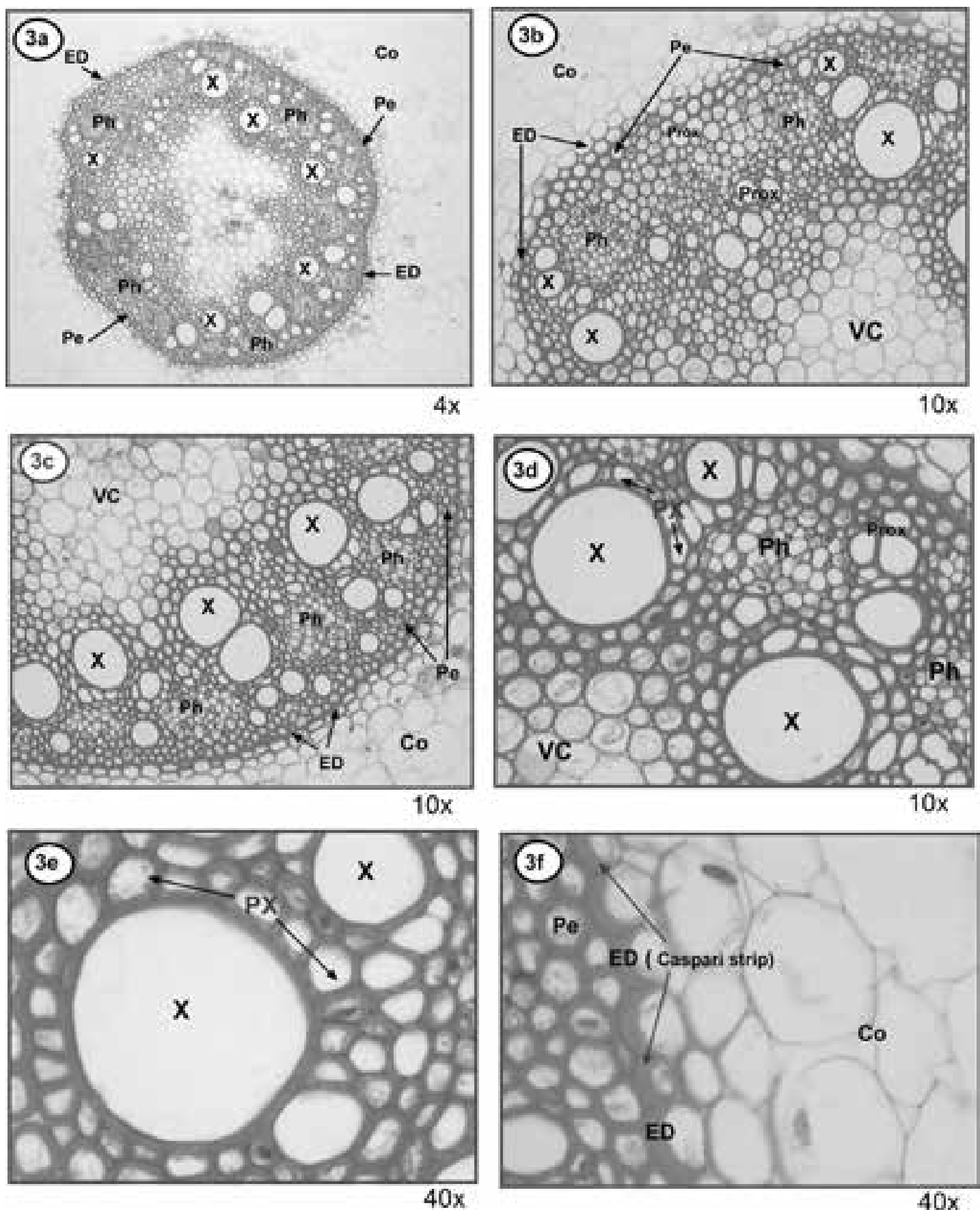

Figure 3. Light micrographs of cross sections of root in plants of Zea mays L. amylacea. Showing the organization of the root tissue

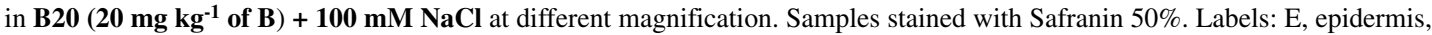
$\mathrm{X}$, xylem; Pe, pericicle, ED, endodermis; Co, cortex cells; Ph, Phloem; VC, vascular cylinder.

was there variation in the size of the cortical cells; similar to that observed in control plants. However, in high salt conditions, and in the presence of B, the appearance of some cortical cells was slightly distorted; they were collapsed, (Figures 4d, 5b and $5 \mathrm{c}$ ). Those specific areas where alterations or changes in the structure are observed are indicated with asterisks $(*)$. Cell walls were thicker 

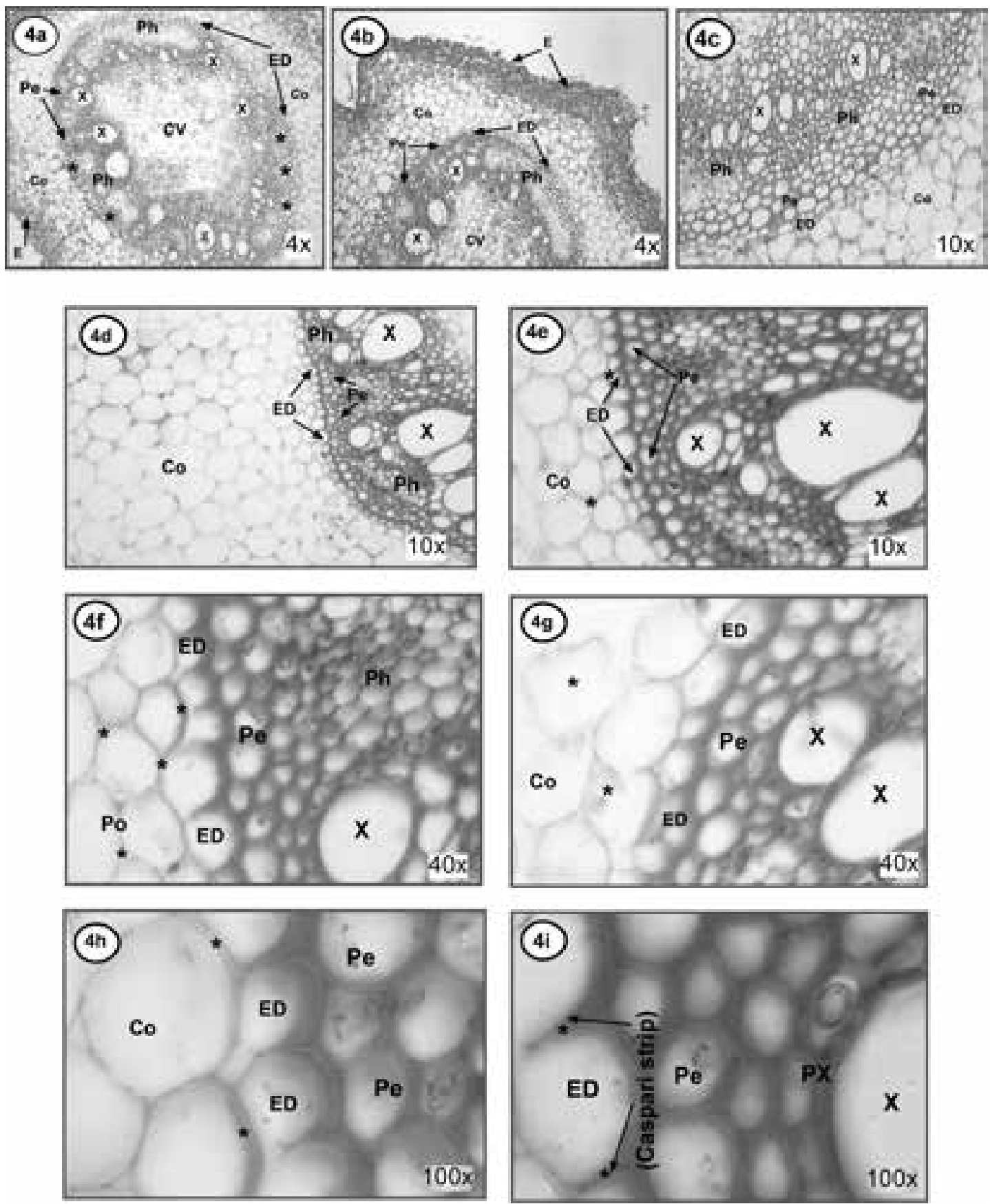

Figure 4. Light micrographs of cross sections of root in plants of Zea mays L. amylacea. Showing the organization of the root tissue in $430 \mathrm{mM} \mathrm{NaCl}$ at different magnification. Samples stained with Safranin 50\%. Labels: E, epidermis, X, xylem; Pe, pericicle, $\mathrm{ED}$, endodermis; Co, cortex cells; $\mathrm{Ph}$, Phloem; VC, vascular cylinder.

(Figures $4 \mathrm{~d}, 4 \mathrm{e}$ and $5 \mathrm{~b}$ ); and in some cells there was a noticeable thickening (Figures $4 \mathrm{~d}$ and $4 \mathrm{e}$ ). In the anatomy and arrangement of xylem and phloem no apparent changes were produced by the levels of B and salinity studied (Figures $2 \mathrm{c}$, $3 \mathrm{c}, 5 \mathrm{c}$ and $5 \mathrm{~h}$ ); the variety of internal diameters of vascular bundles was maintained. The cells of the endoderm in ecotype amylacea in saline conditions 
and with excess B had a similar appearance to the control plants, even at high salt conditions (430 $\mathrm{mM}$ ); in the absence of $\mathrm{B}$, a slight or no significant increase was observed in the thickening of cell walls (Figures $4 \mathrm{e}$ and $5 \mathrm{~d}$ ). The pericycle was made up of one or two rows of cells with small intercellular spaces between them, and between pericycle and endodermis cells (Figures 2c, 3b, 4c and 5d).

In samples at high salinity in the presence of $B$, changes were also detected in pericycle thickness, mainly a marked increase in the number of rows of cells in parts of the stele (Figures $4 \mathrm{~b}$ and $4 \mathrm{a}$ ), which are transformed from 1 to 2 rows of cells in normal conditions to up to 7 rows in high salinity conditions. Increasing the number of rows of cells in plants under high salt did not result in an increase in thickness of the stele, possibly due to a lower number of cells in each row.

\section{Discussion}

Root anatomy of the amylacea ecotype did not appear to be severely affected by treatment of excess B, low or high salinity stress, showing similar morphological characteristics to control plants. This behavior confirms the observations made by Wang et al. (1991), who indicated that the mature root tissues of maize plants after more than 21 days are remarkably resistant to stressors such as drought and salinity. They may also have very low values of relative water content (RWC) in tissues, even below the minimum levels in leaves in herbaceous plants, without making major changes in the structure of tissues (Oppenheimer \& Leshem 1966).

The tissues of the primary root of amylacea ecotype under excess B and interaction with salinity stress (Figures 2, 3, 4 and 5) showed few symptoms of dehydration, cortical cell collapse or increase in the number of rows. Only some slight alterations were observed at high salt conditions, such as irregular appearance of cortical cells, but this damage was not severe enough to dramatically affect root growth. This behavior is confirmed by a slight decrease in root growth of the amylacea ecotype under salt and excess B stress (Bastias et al. 2004b), confirming the high tolerance of this cultivar compared to the behavior described for other cultivars of maize and other crops.

In maize cultivar 225 Collectivnyi important anatomical alterations in the root were produced by salinity $(100 \mathrm{mM} \mathrm{NaCl})$, such as reduction in the number of rows of cells in the cortex and changes in the organization of the stele (Belyavskaya et al. 2004). Furthermore, similar responses were found in maize cultivar saccarata Koern spp. cv Bonanza, but due to the effect of other stresses such as the application of the herbicides chlorsulfuron or ethametsulfuron at low doses. This case reported a significant reduction in root growth, decreasing $55-72 \%$ due to a deformation of the cortex cell wall, possibly inhibiting root growth (Flaburiari \& Kristen 1996). In rice plants (Samarajeewa et al. 1999) and barley (Shabala et al. 2003) induced root salinity has also been described, specifically the effect of osmotic stress and $\mathrm{Na}^{+}$content (Marschner 1995), which caused severe alterations in the root tissue, mainly in the cortical cells, even causing the death of cortical tissue. These damages significantly affected the growth of the primary root of barley, decreasing it by $70 \%$ (Shabala $e t$ al. 2003). It is important to consider the structural alterations in these cultivars and crops occurred after plant roots were subjected to salinity of 100 $\mathrm{mM} \mathrm{NaCl}$, which is a low salinity compared to that used in our study.

The amylacea ecotype showed a high capacity for $\mathrm{Na}^{+}$accumulation in the roots; able to accumulate up to $4 \% \mathrm{Na}^{+}$in the root tissue, while the leaf values were around $1 \% \mathrm{Na}^{+}$(Bastias et al. 2004b). This $\mathrm{Na}^{+}$may be preferentially localized in the cell cortex, referring to results described by Vetterlein et al. (2004) for maize cultivar Pioneer 3906, which also behaves as a $\mathrm{Na}^{+}$excluder, restricting the translocation of $\mathrm{Na}^{+}$from the root portion to the aerial part (Schubert \& Läuchli 1986, 1990). Limiting the entry of $\mathrm{Na}^{+}$into the stele is performed at the level of the plasma membrane in cells and cortical cells of the epidermis (Vetterlein et al. 2004). Similar results have also been described in another cultivar of maize cv F1 3906 (Zorb et al. 2005) and barley plants (Wegner \& Raschke 1994) grown in saline conditions, where an increase of $\mathrm{Na}^{+}$was observed in the vacuoles of the cell cortex. They further concluded that the storage capacity of $\mathrm{Na}^{+}$in the cortex is generally greater than that of the xylem parenchyma cells.

The changes in the fine structure of the root are promoted by suberization salinity induced in the hypodermis and endodermis (Shannon et al. 1994). The Casparian strip implies the presence of an apoplastic barrier between the cortex and 
the stele in plant stems and roots. This barrier is formed by endodermal cells and contributes to form a highly organized network of primary walls. The cell wall of the Casparian strip is impregnated with hydrophobic molecules such as suberin, and the plasma membrane adheres strongly to the cell wall of the endodermis. As a result, apoplastic ion flow is restricted in the endoderm, so that this barrier appears to play an important role in preventing high salt entry into the stele under saline conditions (Karahara et al. 2004). It is therefore important to know whether a morphological change occurs in the structure of this barrier, which can act as a morphological strategy to limit the entry of salts to the vascular bundles of the stele. In the endodermis of amylacea ecotype (Figures $5 \mathrm{~d}, 5 \mathrm{e}$, $5 f$ and $5 \mathrm{~g}$ ) some compaction of the cells that make up the Casparian strip was observed, although an increase in radical band width was observed (Zimmermann et al. 2000). This lack of effect on the Casparian strip in the amylacea ecotype is contradictory to the effect described by Karahara et al. (2004) in maize roots and ssp Sacchorata and by Reinhardt \& Rost (1995) in cotton roots. These authors showed that in saline conditions increased thickness of Casparian strip cells in primary root endodermis occurred. Changes in the thickness of the Casparian strip may have an important function in strengthening the barrier of the apoplastic transport factor, enhancing the hydraulic resistance of the endodermis due to higher density of hydrophobic materials such as suberin and lignin (Karahara et al. 2004). However, no thickening of the Casparian strip in the root tissue of ecotype amylacea as an effect of salinity would not be a disadvantage for the passage of water. This is evidenced in part by the optimal values of RWC found in the leaf (about 91\%) (Bastias et al. 2004b) even under severe salt stress. Barrieu et al. (1998) in corn root cv Oh43, found mRNA encoding aquaporins of the tonoplast, which were expressed at a high level in this region of the root, specifically in the endodermal cells and pericycle, confirming the transport of water by this pathway. Clearly the Casparian strip in the case of salinized plants would not further restrict the passage of water (Lehmann et al. 2000, Chen et al. 2011). In the case of the amylacea ecotype, decreased root hydraulic conductance was observed in saline conditions (Bastias et al. 2004a).
The pericycle, endodermis along represents the interface between the cortex and the stele of the root; the two layers of cells are an important site in the regulation of long-range transport of ions via xylem and phloem. In the amylacea ecotype, an increased number of rows of cells that form the pericycle in parts of the stele (Figures $4 a$ and 4c) were observed, although this change was seen only in high salinity. This increase in the number of rows of cells in the pericycle is accompanied by the presence of smaller cell sizes, a behavior that probably increases the resistance of cells against collapsing under conditions of stress (Oertli 1990). This would also increase the ability of plants to maintain turgor, especially under conditions of water stress (Jones \& Turner 1980). This resistance can be increased by around 20 times when the cells forming the pericycle are smaller compared to larger cells (Bosabalidis \& Kofidis 2002). Thus the presence of a large number of smaller cell sizes for tissue surface remarkably improved water loss control under conditions of salt stress (Oertli 1990; Bosabalidis \& Kofidis 2002). Moreover, the decrease in cell size could be due to the cells of the endodermis and pericycle being fully differentiated in the root, which allows a relatively large cytoplasmic region in both cell types where they can deposit significant levels of ions that are subsequently distributed between the cytoplasm and the cell vacuoles (Storey et al. 2003). Indeed, X-ray microanalysis performed in primary root vines and Puccinellia tenuiflora grown in saline conditions showed that $\mathrm{Na}^{+}$was mainly distributed in the vacuoles of the pericycle cells in vines and into the intercellular spaces of the endodermis in P. tenuiflora (Storey et al. 2003; Peng et al. 2004). In our case, we know from the data of $\mathrm{Na}^{+}$accumulated in the roots and in the aerial part that the amylacea ecotype handles the movement of $\mathrm{Na}^{+}$within the plant at the root level, so we suggest that $\mathrm{Na}^{+}$accumulation could occur mainly in cells of the cortex and secondly in the endodermis and pericycle. Thus the entry of $\mathrm{Na}^{+}$ would be restricted to the aerial part of the plant, as shown by low levels of $\mathrm{Na}^{+}$found in leaf tissue.

Within the literature, it is shown that salinity causes increased lignification in the vascular bundles of the root, which increases the vascular cylinder and is manifested in a thickening of the cell wall of xylem vessels and consequently root diameter (Kalaji \& Pietkiewicz 1993, Shannon et al. 1994). 

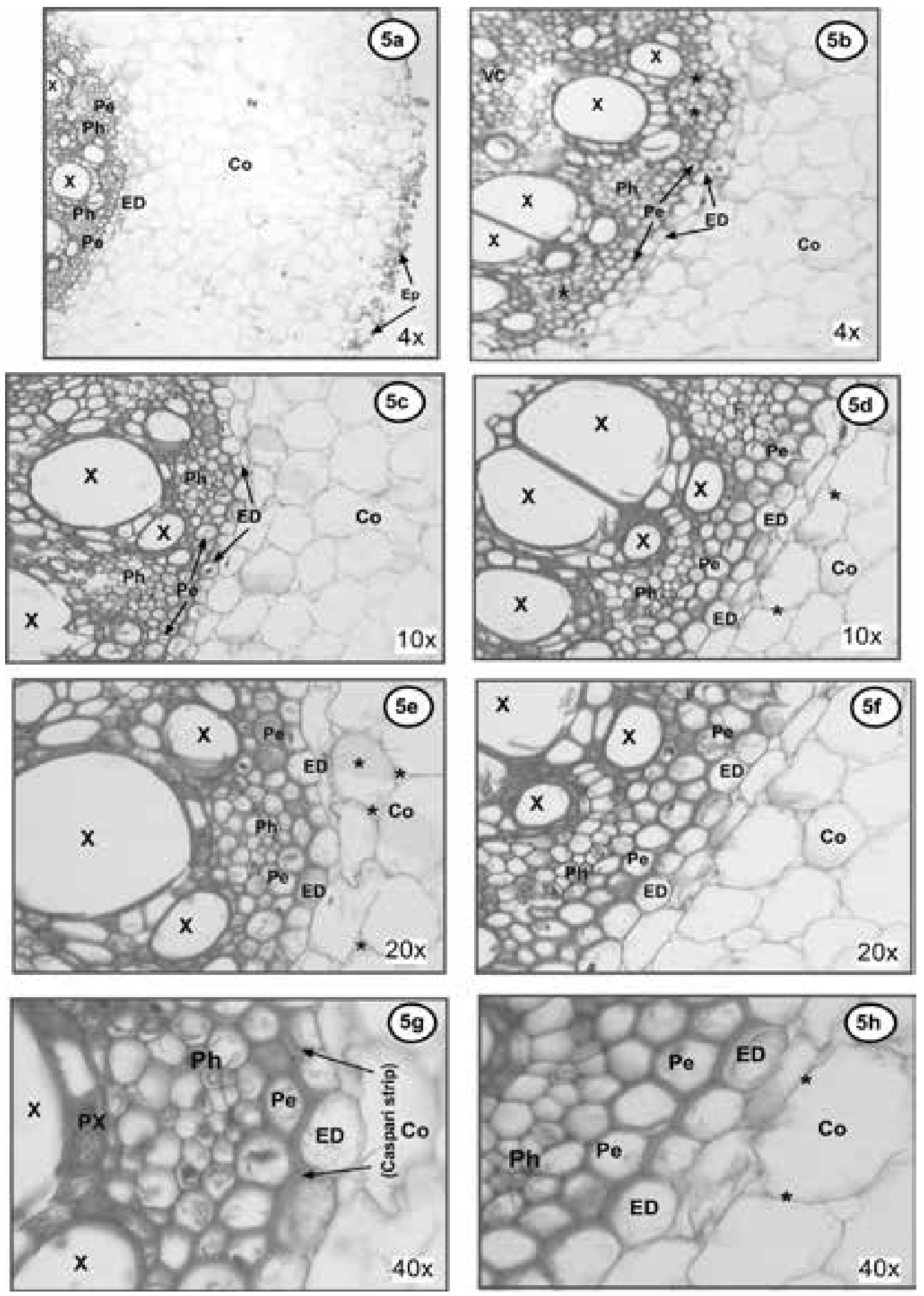

Figure 5. Light micrographs of cross sections of root in plants of Zea mays L. amylacea. Showing the organization of the root tissue in $\mathbf{B} 40$ (40 $\mathrm{mg} \mathrm{kg}^{-1}$ of $\left.\mathbf{B}\right)+\mathbf{4 3 0} \mathbf{~ m M ~ N a C l}$ at different magnification. Samples stained with Safranin 50\%. Labels: E, epidermis, $\mathrm{X}$, xylem; Pe, pericicle, ED, endodermis; Co, cortex cells; Ph, Phloem; VC, vascular cylinder. 
This effect was observed in cotton (Kurth et al. 1986) and bean plants (Cachorro et al. 1994). Conversely, Strogonov et al. (1964) found no difference in the diameter of the root in tomato and cotton plants under salinity for 4 weeks and Huang \& Redmann (1995) also observed this behavior in barley plants under saline conditions. However, these authors did associate salinity with the presence of a large number of small diameter vessels in the root. According to our results, we suggest that the amylacea ecotype response to high salinity stress and excess B (Figures 1c, 2a, 3c, 4c and 5c) is essentially the maintenance of anatomic properties similar to those of control plants, not showing any of the disorders described above for other crops. Thus, the area occupied by the xylem vessels and surface distribution, the proportion occupied by the stele and cortex of the root and the number of rows of cortical cells were not altered.

\section{Conclusions}

In this study, roots of amylacea ecotype did not develop visible symptoms of B toxicity that could be reflected in any alteration of the anatomy of the root tissue. This result is likely because the concentration of B in the root remained low, with values of around $20 \mathrm{ppm} \mathrm{B}$, compared to the levels found in leaf both in non-salt and salt conditions, with values of around $800 \mathrm{ppm} \mathrm{B}$ (Figures 2c and 2d) (Bastias et al. 2004b), even when there was high availability of $B$ in the external medium (Oertli 1990; Nable et al. 1997). This characteristic may be attributed in part to the binding of B with some molecules of the cell wall of the root cells, which would reduce the amount of B in the cytoplasm, causing it not to accumulate to potentially toxic levels. The ability of plants to recognize and respond to specific stress combinations is particularly important when those individual stresses could elicit negative effects on plant growth and reproduction, whereas others indicate a positive role of the interaction of multiple stresses, compared to individual stresses applied separately (Sukuki et al. 2014), as in the case of "lluteño" maize (Zea mays amylacea).

\section{Acknowledgements}

This study was funded partly by Project UTAMayor 9720-13 and Proyecto FIC P117 Código BIP 30158423-0 (Arica-Chile).

\section{Literature Cited}

Atkinson, N.J.; Urwin, P.E.

2012. The interaction of plant biotic and abiotic stresses: from genes to the field. Journal of Experimental Botany, 63: 3523-3543.

Barrieu F.; Chaumont, F.; Chrispeels, M. 1998. High Expression of the Tonoplast Aquaporin ZmTIP1 in Epidermal and Conducting Tissue of Maize. Plant Physiology, 117: 1153-1163.

Bastías E.; Fernández-García, N.; Carvajal, M.

2004A. Aquaporin functionality in rotos of Zea mays in relation to the interactive effects of boron and salinity. Plant Biology, 6: 415-421.

Bastías, E.; González-Moro, M.B.; González-Murua, C. 2004b. Zea mays L. amylacea from the Lluta Valley (AricaChile) tolerates salinity stress when high levels of boron are available. Plant and Soil, 267: 73-84.

Bastías, E.; González-Moro, M.B.; González-Murua, C. 2013. Interactive effects of excess boron and salinity on histological and ultrastructure leaves of Zea mays amylacea from Lluta Valley (Arica-Chile). Ciencia e Investigacion Agraria, 40: 589-603.

Bastías, E.; González-Moro, M.B.; González-Murua, C. 2013. Leaf micromorphology in Zea mays amylacea from Lluta Valley (Arica-Chile) with excess boron and salinity. Idesia, 31: 75-80.
Belyavskaya N.; Zhuk, O.; Kurilenko, A.; Palladina, T. 2004. Morphogenesis of maize primary roots in relation to salinity and methyure effects. Growth and development of plants. Theorical and practical problems. Abstracts of International Scientific Conference. Lithuanian Institute of Horticulture, Babtai. p. 26.

Bosabalidis A.; Kofidis, G.

2002. Comparative effects of drought stress on leaf anatomy of two olive cultivars. Plant Science, 163: 375-379.

Cachorro, P.; Ortiz, A.; Cerdá, A.

1994. Implications of calcium nutrition on the response of Phaseolus vulgaris L. to salinity. Plant and Soil, 159: 205-212. FAO.

2008. Land and Plant Nutrition Management Service. http:// www.fao.org/ag/agl/agll/spush.

Flaburiari, A.; Kristen, U.

1996. The influence of chlorsulfuron and metsulfuron methyl on root growth and on the ultrastructure of root tips of germinating maize seeds. Plant and Soil, 180: 19-28.

Flowers, T.J.; Hajibagheri, M.A.; Clipson, N.J.W.

1986. Halophytes. Quarterly Review of Biology, 61: 313-337. González-Moro, B.; Lacuesta, M.; Becerril, J.M.; González-Murua,

C.; Muñoz-Rueda, A.

1997. Glycolate accumulation causes a decrease of photosynthesis by inhibiting RUBISCO activity in maize. Journal of Plant Physiology, 150: 388-394. 
Hajibagheri, M.A.; Harvey, D.M.R.; Flowers, T.J.

1987. Quantitative ion distribution within root cells of saltsensitive and salt-tolerant maize varieties. New Phytologist, 105: 367-379.

Hakim, M.A.; Juraimi, A.S.; Hanafi, M.M.; Ismail, M.R.; Selamat, A.; Rafii, M.Y.; Latif, M.A.

2014. Biochemical and Anatomical Changes and Yield Reduction in Rice (Oryza sativa L.) under Varied Salinity Regimes. BioMed Research International, 11 p.

Hernández, J.A.; Almanza, M.S.

2002. Short-term effects of salt stress on antioxidant systems and leaf water relations of pea leaves. Physiologia Plantarum, 115: 251-257.

Huang, J.; Redmann, R.E.

1995. Physiological responses of canola and wild mustard to salinity and contrasting Ca supply. Journal of Plant Nutrition, 18: 1931-1949.

Jeschke, W.D.; Wolf. O.

1988. External potassium supply is not required for root growth in saline conditions: experiments with Ricinus communis L. grown in a reciprocal split-root system. Journal of Experimental Botany, 39: 1149-1167.

Jones, M.M.; Turner. N.C.

1980. Osmotic adjustment in expanding and fully expanded leaves of sunflower in response to water deficits. Functional Plant Biology, 7: 181-192.

Kalaji, M.H.; Pietkiewicz. S.

1993. Salinity effects on plant growth and other physiological processes. Acta Physiologiae Plantarum, 15: 89-124.

Karahara, I.; Ikeda, A.; Kondo. T.

2004. Development of the Casparian strip in primary roots of maize under salt stress. Planta, 219: 41-47.

Marschner, $\mathrm{H}$.

1995. Mineral Nutrition of Higher Plants. Academic Press Limited, London UK. 889 pp.

Martínez-Ballesta, M.C.; Bastías, E.; Zhu, C.; Schäffner, A.R.;

González-Moro, B.; González-Murua C.; Carvajal, M.

2008. Boric acid and salinity effects on maize roots. Response of aquaporins $Z m P I P 1$ and $Z m P I P 2$, and plasma membrana $\mathrm{H}^{+}$-ATPase, in relation to water and nutrient uptake. Physiology Plantarum, 132: 479-490.

Mittler, R.

2006. Abiotic stress, the field environment and stress combination. Trends in Plant Science, 11: 1-19.

Nable, R.O.; Bañuelos, G.S.; Paull, J.G.

1997. Boron Toxicity. Plant and Soil, 193: 181-198.

Neuman, P.M.

1995. Inhibition of root growth by salinity stress: Toxicity or an adaptive biophysical response. In: Structure and Function of Root. Baluska F., Ciamporová M., Gaspariková O. Barlow P.W. (Eds.). The Netherlands: Kluwer Academic Publisher. pp. 299-304.

Oertli, J.J.

1990. The distribution of normal and toxic amounts of boron in leaves of rough lemon. Agronomy Journal, 52: 530-532.
Peng, Y.H.; Zhu, Y.F.; Mao, Y.Q.; Wang, S.M.; SU, W.A; Tang, Z.CH.

2004. Alkali grass resist salt stress through high $\left[\mathrm{K}^{+}\right]$and an endodermis barrier to $\mathrm{Na}^{+}$. Journal of Experimental Botany, 398: 938-949.

Reinhardt, D.H.; Rost, T.L.

1995. Salinity accelerates endodermal development and induces an exodermis in cotton seedling root. Environmental and Experimental Botany, 35: 563-574.

Samarajeewa, P.K.; Barrero, R.A.; Umeda-Hara, C.; Kawai, M.; Uchimiya. H.

1999. Cortical cell death, cell proliferation, macromolecular movements and rTip1 expression pattern in roots of rice (Oryza sativa L.) under $\mathrm{NaCl}$ stress. Planta, 207: 354-361.

Schubert, S.; Läuchli. A.

1990. Sodium exclusion mechanisms at the root surface of two maize cultivars. Plant and Soil, 123: 205-209.

Shabala, S.; Shabala, L.; Van Volkenburg, E.

2003. Effects of calcium on root development and root ion fluxes in salinized barley seedling. Functional Plant Biology 30: $507-514$.

Shannon, M.C.; Grieve, C.M.; Francois, L.E.

1994. Whole plant response to salinity. In Wilkinson RE (Ed.) Plant Environment Interactions. New York: Marcel Dekker pp. 199-244.

Storey, R.; Schachtman, D.P.; Thomas, M.R.

2003. Root structure and cellular chloride, sodium and potassium distribution in salinized grapevines. Plant, Cell and Environment, 26: 789-800.

Strogonov, B.P.; Poljakoff-Mayber, A.; Mayer, A.M.

1964. Physiological basis of salt tolerance of plants (as affected by various types of salinity).

Valenti, S.; Melone, L.; Orsi, O.; Rivero, F.

1992. Anatomical changes in Prosopis cineraria (L.) Druce seedlings growing at different levels of $\mathrm{NaCl}$. salinity. Annals of Botany, 70: 399-404.

Wahida, A.; Javed, I-UL-H.; Ali, I.; Baig, A.; Rasul, E.

1998. Short term incubation of Sorghum caryopsis in sodium chloride levels: changes in pre- and post-germination physiological parameters. Plant Science, 139: 223-232.

Wang, X.L.; Canny, M.J.; Mccully, M.E.

1991. The water status of the roots of soil-grown maize in relation to the maturity of their xylem. Physiologia Plantarum, 82: $157-162$.

Zimmermann, H.M.; Hartmann, K.; Schreiber, L.; Steudle, E. 2000. Chemical composition of apoplastic transport barriers in relation to radial hydraulic conductivity of maize roots (Zea mays L.). Planta, 210: 302-311.

Zorb, C.; Noll, A.; Karl, S.; Leib, K.; Yan F.; Schubert. S. 2005. Molecular characterization of $\mathrm{Na}^{+} / \mathrm{H}^{+}$antiporters (ZmNHX) of maize (Zea mays L.) and their expression under salt stress. Journal of Plant Physiology, 162: 55-66. 